\title{
Profile of Misconception in Senior High School Students on the Concept of Acid-Base Strength
}

\author{
Wiwi Siswaningsih ${ }^{1}, \mathrm{Nahadi}^{2}$, Vina Chandratika ${ }^{3}$ \\ \{wiwi2450@gmail.com ${ }^{1}$, nahadi@upi.edu ${ }^{2}$, vina.cht@gmail.com ${ }^{3}$ \} \\ Department of Chemistry Education, FPMIPA UPI ${ }^{1,2,3}$
}

\begin{abstract}
This research aimed to find out the profile of misconception in senior high school students on the concept of acid-base strength and its factors causing. The research design used was qualitative descriptive. The data collection was carried out by two-tier pictorial multiple-choice diagnostic tests on the concept of acid-base strength modified by the previous researcher from, which consist of seven items and had been valid and reliable. In addition, the data were collected by using a questionnaire, interviews with students who's having misconceptions and the chemistry teachers who taught the students, and documentation of a chemistry textbook. The findings showed that: (1) students having misconceptions on the concept of acid-base strength; (2) the biggest misconception was the target concept of the relationship between acid strength and $\mathrm{pH}$ with a percentage of $51.52 \%$; (3) student misconception was caused by various factors, namely the condition of students, experiences, teachers, and textbooks.
\end{abstract}

Keywords: Acid-Base Strength, Diagnostic Test, Misconception, Profile, Two-Tier Multiple-Choice Test

\section{Introduction}

Based on several research results, it showed that one of the important problems in education, especially in science, was misconception [1]. Misconception is a conception that is built by students based on experience that is not in accordance with scientific concepts [2]. The existence of this misconception can affect the development of student understanding and inhibit the learning process of subsequent students because the misconception causes the new knowledge possessed by students cannot be linked to cognitive knowledge so that students' understanding of concepts becomes weak [3].

The students' misconceptions can be caused by various factors, both internal and external factors. Internal factors that influence the formation of students' misconceptions include preconceptions, associative thinking, humanistic thinking, wrong intuition, stages of cognitive development, incomplete/incorrect reasoning, ability, and interest in learning [4], while external factors that influence include everyday experiences, teachers, textbooks, and language used [5]. Chemistry is a branch of science that is continuous, which is interconnected between one concept and another. One of the essential chemistry concepts contained in the 2013 curriculum for high school students in class XI in the science program [6] and many misconceptions were found based on several research results, namely the concept of acid-base strength [7]. 
Misconceptions about these concepts can be identified using diagnostic tests. A diagnostic test is a test that aims to determine precisely the type of difficulty faced by students, in this case, misconceptions [8]. The most widely used diagnostic test is the two-tier multiple-choice that was first developed by Treagust [9]. The diagnostic test used in this study is two-tier pictorial multiple choice. Pictorial test is a test that involves pictures or representations made with certain meanings to describe people, things, and places [10]. The existence of pictures can help students who have difficulty answering in sentence [11]. Results from diagnostic tests are recorded and reported in profile [12]. Misconception profile is a graphic or writing that illustrates students' misconceptions based on data [13]. If the profile and the factors causing misconceptions have been found, the teacher can design appropriate learning strategies to be applied to the concept, so that in the future students understand the concept completely and not cause misconceptions $[5]$.

Based on the results of preliminary analysis conducted through interviews with a number of class XI students and chemistry teachers in an area in the province of West Java, it was known that students were identified as having a misconception on the concept of acid-base strength. In addition, teachers generally did not conduct diagnostic tests to identify students' misconceptions, but only formative and summative tests. Therefore, this study aimed to determine the profile and causes of misconceptions of class XI high school students in the region on the concept of acid-base strength.

\section{Method}

The design of this research was descriptive qualitative. The descriptive method is a method that describes and interprets the object or subject of research as is [14]. Participants in this study were high school students of class XI who have studied acid-base material and chemistry teachers who teach in schools that serve as a place of research. This research was conducted in 3 high schools in Sumedang Regency, a city area.

The determination of participants in this study was done purposively, which was determined by adjusting the research objectives [15]. From each school used as a place of research, selected class XI high school students who have studied acid-base material as much as $\pm 20 \%$, so that the number of students who participated in this study were 198 people.

There were four types of instruments used in this research, namely a two-tier pictorial multiple-choice diagnostic test on the concept of acid-base strength modified by researchers from previous developers that have been valid and reliable, interview guidelines, questionnaires, and documentation guidelines for student chemistry handbooks on the concept of acid-base strength.

Data obtained based on the instruments used were analyzed descriptively to find out the misconceptions experienced by students and their causal factors. These data analysis consists of several steps, namely: (1) processing response patterns of student responses consisting of 16 response patterns for each item, then calculating the percentage for each response pattern chosen by students; (2) the classification of response patterns of students' answers into three categories of students conception, namely understanding, misunderstanding, and misconception. Student understands the concept if the response pattern of the answer is in accordance with scientific concepts, misunderstands the concept if the response pattern is not in accordance with scientific concepts and the answers at the first tier are not related to the answers at the second tier, and 
misconceptions if the response patterns do not match the scientific concepts and answers at the first tier interrelated with answers at the second tier [16]; (3) determination of significant student misconceptions, namely misconceptions with a percentage $\geq 10 \%$ of the total number of students as participants [16]; (4) analyzing and describing students' misconceptions on the concept of acid-base strength and its causal factors based on all data obtained from the four types of instruments used.

\section{Result and Discuss}

Based on the response patterns of students' answers on the two-tier multiplechoice diagnostic test the concept of acid-base strength, it was known that high school students of class XI in Sumedang Regency were identified as having misconceptions on the seven target concepts tested, with the percentage of each shown in Figure 1.

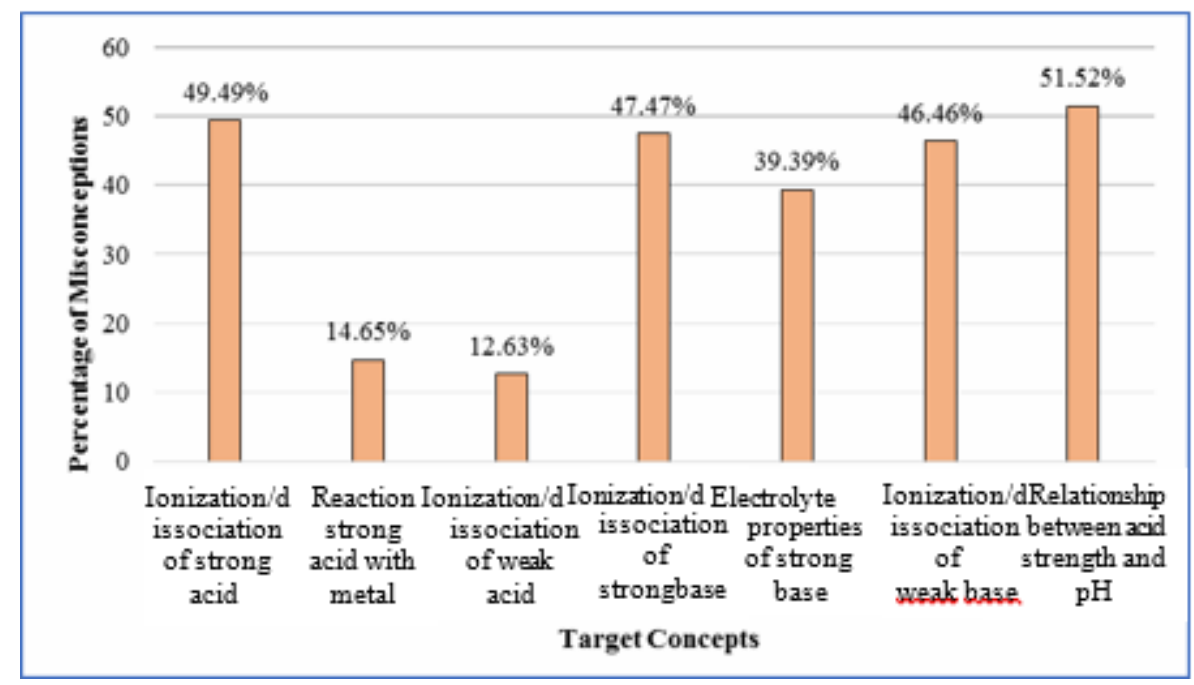

Fig. 1. Percentage graph of student misconceptions on each target concept.

Based on Figure 1., it was known that the highest percentage of students 'misconceptions on the concept of acid-base strength was found in the concept of the relationship between acid strength and $\mathrm{pH}$ with a percentage of $51.52 \%$, while the smallest percentage of students' misconceptions was on the target concept of ionization/dissociation weak acid with a percentage of $12.63 \%$.

The significant misconceptions identified were experienced by class XI high school students in Sumedang Regency on the concept of acid-base strength shown in Table 1. 
Tabel 1. Significant student misconceptions about the concept of acid-base strength.

\begin{tabular}{|c|c|c|c|}
\hline $\begin{array}{c}\text { Target } \\
\text { Concept }\end{array}$ & Misconception & $\begin{array}{l}\text { Number of } \\
\text { Students }\end{array}$ & $\begin{array}{c}\text { Percentage } \\
(\%)\end{array}$ \\
\hline \multirow[t]{3}{*}{$\begin{array}{l}\text { Ionization/dis } \\
\text { sociation }\end{array}$} & $\begin{array}{l}\text { Strong acid ionize/dissociate completely in water, so } \\
\text { submicroscopically in the solution, there are cations } \\
\left(\mathrm{H}_{3} \mathrm{O}^{+}\right) \text {, }\end{array}$ & 35 & 17.68 \\
\hline & anions, acid molecules, and $\mathrm{H}_{2} \mathrm{O}$. molecules. & & \\
\hline & $\begin{array}{l}\text { Strong acid ionize/dissociate in water so that it is } \\
\text { submiscroscopically in its solution with a water solvent still } \\
\text { in the state of its molecules. }\end{array}$ & 26 & 13.13 \\
\hline \multirow[t]{2}{*}{$\begin{array}{l}\text { Ionization/D } \\
\text { issociation } \\
\text { of StrongBase }\end{array}$} & $\begin{array}{l}\text { Strong base ionize/dissociate completely in a water solvent } \\
\text { so that in the solution there are anions }\left(\mathrm{OH}^{-}\right) \text {, cations, base } \\
\text { molecules, and } \mathrm{H}_{2} \mathrm{O} \text { molecules. }\end{array}$ & 38 & 19.19 \\
\hline & $\begin{array}{l}\text { The strong base does not ionize/dissociate in a water solvent } \\
\text { so that the solution is still in the state of its molecules } \\
\text { namely base molecules and } \mathrm{H}_{2} \mathrm{O} \text { molecules. }\end{array}$ & 22 & 11.11 \\
\hline \multirow{3}{*}{$\begin{array}{l}\text { Electrolyte } \\
\text { Properties } \\
\text { of Strong } \\
\text { Base }\end{array}$} & Strong base solution ionizes/dissociates completely in & & \\
\hline & $\begin{array}{l}\text { solution and cannot conduct electricity as evidenced by the } \\
\text { no-ignition of the lamp on the electrical conductivity tester. }\end{array}$ & 34 & 17.17 \\
\hline & $\begin{array}{l}\text { Strong base solutionionize/dissociate partially in solution } \\
\text { and can conduct electricity as evidenced by the dim lights on } \\
\text { the electrical conductivity test. }\end{array}$ & 26 & 13.13 \\
\hline \multirow[t]{2}{*}{$\begin{array}{l}\text { Ionization/Di } \\
\text { ssociation of } \\
\text { weak base }\end{array}$} & $\begin{array}{l}\text { A base such as } \mathrm{Fe}(\mathrm{OH})_{2} \text { which has a dissociation constant }< \\
1 \text { is a weak base that dissociates partially in a water solvent } \\
\text { to produce a small amount of } \mathrm{Fe}^{2+} \text { ions and } \mathrm{OH}^{-} \text {ions. In } \\
\text { submicroscopic depiction of } \mathrm{Fe}(\mathrm{OH})_{2} \text { solution with water } \\
\text { solvent there are } 2 \mathrm{Fe}^{2+} \text { ions, } 2 \mathrm{OH}^{-} \text {ions, } 1 \\
\mathrm{Fe}(\mathrm{OH})_{2} \text { molecule, and } \mathrm{H}_{2} \mathrm{O} \text { molecules. }\end{array}$ & 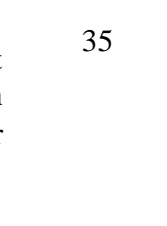 & 17.68 \\
\hline & $\begin{array}{l}\text { A base such as } \mathrm{Fe}(\mathrm{OH})_{2} \text { which has a dissociation constant }<1 \\
\text { is a weak base that dissociates completely in a water solvent } \\
\text { producing many } \mathrm{Fe}^{2+} \text { ions and } \mathrm{OH}^{-} \text {ions. In submicroscopic } \\
\text { depictions of } \mathrm{Fe}(\mathrm{OH})_{2} \text { solution in aqueous } \\
\text { solvent there are } \mathrm{Fe}^{2+} \text { ions, } \mathrm{OH}^{-} \text {ions, and } \mathrm{H}_{2} \mathrm{O} \text { molecules. }\end{array}$ & 22 & 11.11 \\
\hline $\begin{array}{l}\text { Relationship } \\
\text { between Acid }\end{array}$ & $\begin{array}{l}\text { The higher the } \mathrm{pH} \text { value, the stronger the acidic of a } \\
\text { solution because } \mathrm{pH} \text { indicates the strength of the acid. }\end{array}$ & 77 & 38.89 \\
\hline $\begin{array}{l}\text { Strength and } \\
\text { pH }\end{array}$ & $\begin{array}{l}\text { The lower the } \mathrm{pH} \text { value, the stronger the acidic of a solution } \\
\text { because } \mathrm{pH} \text { indicates the strength of the acid. }\end{array}$ & 24 & 12.12 \\
\hline
\end{tabular}

Based on Table 1., it was known that from the 7 target concepts tested to explore students' misconceptions on the concept of acid-base strength, there were 5 target concepts that showed significant student misconceptions, namely the concept of ionization/dissociation of strong acid, ionization/dissociation of strong base, electrolyte properties of strong base, ionization/dissociation of weak base, and the relationship between acid strength and $\mathrm{pH}$.

In addition to the misconceptions that had been described above, there were several other misconceptions found in this research that were obtained based on the results of interviews with students, including students who thought that:

- submicroscopic depiction of an acid/base solution based on the reaction equation, so that both the reactants and the product must always be present in the submicroscopic depiction, even though the acid/base ionize/dissociate completely in the solution; 
- in submicroscopic depictions of a weak acid/base solution it is not necessary to pay attention to the number of ions it produces, but only the presence or absence of molecules or compounds which do not ionize/dissociate into ions;

- proton $\left(\mathrm{H}^{+}\right)$ionized by acidic compounds in aqueous solution with water is a free proton $\left(\mathrm{H}^{+}\right)$, not chemically bound to water molecules;

- in a basic solution with a water solvent there are no $\mathrm{H}^{+}(\mathrm{aq})$ ions;

- a strong base such as $\mathrm{NaOH}$ does not dissociate in solution with a water solvent but ionize.

Student misconceptions that were identified in this research were caused by various factors. Based on students 'responses to the statements on the questionnaire, it was known that the factors that influence the formation of students' misconceptions on the concept of acid-base strength are shown in Table 2.

Table 2. Factors that influence the formation of student misconceptions on the concept of acidbase strength.

\begin{aligned} & \hline FACTOR INDICATOR \\ & \hline Teacher Teaching methods \\ & Textbook High level of student confidence in teachers \\ & Completeness and lack of clarity \\ & Incorrect perception \\ & Student Incorrect associative thinking \\ & Incomplete/incorrect reasoning \\ & Low student ability \\ & \hline\end{aligned}

Based on Table 2. it is known that the factors that influence the formation of students' misconceptions on the concept of acid-base strength consist of internal factors and external factors. The following will describe the factors that influence the formation of a significant student misconception as shown in Table 1.

\subsection{Ionization/Dissociation of Strong Acid/Base}

In general, the pattern of significant misconceptions on the target concept of ionization/ dissociation of strong acids and strong bases was the same. Students assume that even though strong acids/strong bases ionize/dissociate completely, but in the solution, there were acid/base molecules. This was based on their reasoning that the submicroscopic depiction of an acid/base solution was based on the components present in the reaction equation, so that both the reactant component and the product must always be present in the submicroscopic depiction, even though the acid/base ionize/dissociate completely in the solution. This misconception was in line with the results of research by Dewi (2015) [17] and Suryaningtyas (2016) [18] that students assume that strong acids/bases ionize/dissociate completely in a solution producing many cations, anions, and molecules. Based on the results of interviews with students and chemistry teachers, it was known that students make incomplete/wrong reasoning because the teacher did not emphasize the explanation of submicroscopic depictions of an acid/base solution. These findings reinforce previous findings which state that students' reasoning was incomplete/wrong 
and the instructional method used by teachers was a factor that causes students to experience misconceptions [4].

Another misconception pattern in this target concept was students assume that strong acids and strong bases did not ionize/dissociate in water because the intramolecular force on strong acids/bases was very strong, so submicroscopically in the solution with the water solvent, it was still in the state of its molecules. This misconception was in line with the results of research conducted by Demircioglu, et al. (2005) [19] and Artdej, et al. (2010) [20] who suggested that the intramolecular force on strong acids is so strong that strong acids are difficult to ionize/dissociate in water. Like strong acids, strong bases also have strong bonds among molecules [21].

Based on the results of interviews with students who experienced misconceptions on this concept, it was known that students did not understand the concept fully and deeply, but instead drew conclusions from words integrated into their cognitive structures and related them to material that had been previously studied. Students had this understanding because of the same word that was strong. Though strong bases and strong intramolecular forces have different meanings and the relationship between the two is inversely proportional.

The correct concept of this target concept is that strong acids/bases ionize/dissociate completely or almost completely into ions when they are in a water solvent so that the percentage of dissociation $\approx 100 \%$ or the degree of dissociation/dissociation $\approx 1$ [22]. In a solution of strong acids or strong bases with a water solvent, there are essentially no acid or base molecules in the solution, $\left[\mathrm{H}_{3} \mathrm{O}^{+}\right.$or $\left.\mathrm{OH}^{-}\right] \approx$ acid or base molecule] initially or in other words, [acid or base molecule] eq $\approx 0$. For binary acids, such as $\mathrm{HI}$ as stated in the items tested, the ease of ionization depends on two things, namely (1) the ease of breaking $\mathrm{H}-\mathrm{X}$ bonds and (2) the stability of the ions produced in solution [23]. The strong acid ionizes/dissociate completely in solution because the bond or intramolecular force is weak so it is easier to ionize/dissociate and the ions produced in the solution are relatively stable. For strong bases, such as $\mathrm{NaOH}$ as stated in the items being tested, are ionic compounds that dissolve easily in water, so according to Arrhenius's theory when sodium hydroxide $(\mathrm{NaOH})$ is dissolved in water, it dissociates completely into its ions, $\mathrm{OH}^{-}$ions and $\mathrm{Na}^{+}$ions.

\subsection{Electrolyte Properties of Strong Base}

The results showed a significant misconception on the target concept of strong base electrolyte properties consisting of two patterns of misconception. This misconception was formed due to the lack of students' understanding of the concept of acid-base learning prerequisites namely electrolyte and non-electrolyte solution material, as well as coupled with student learning experiences related to the improper nature of base solution electrolytes. These findings reinforced previous findings stating that students' preconceptions were wrong [4] and knowledge that was rooted in experimental experience will directly strengthen student misconceptions [5].

The correct concept on the target concept of strong base electrolyte properties is that strong base solutions can conduct electric current or also called electrolyte solutions. Acids and bases are electrolytes in water, so the classification of strengths of acid bases is related to the classification of electrolyte strengths: strong electrolytes dissociate/ionize completely and weak electrolytes dissociate/ionize partially. Strong electrolyte solutions have strong electrical conductivity, whereas weak electrolyte solutions have weak electrical conductivity [22].

\subsection{Ionization/Dissociation of Weak Base}


The results showed a significant misconception on the target concept of ionization/ dissociation of a weak base consisting of two patterns of misconception. The first pattern of misconception formed due to students' reasoning was wrong in submicroscopic depictions of weak acid/base solutions. Students assumed that submicroscopic depictions of weak acid/base solutions need not pay attention to the number of ions they produce, but only note that there are still molecules or compounds which are not ionized/dissociated into the ions. If there are still molecules or compounds that are not ionized/dissociated into the ions it means the submicroscopic depiction of a weak acid/base solution is appropriate, because weak acids/ bases dissociate partially. The second pattern of misconception formed because students did not understand the meaning of the low ionization constant and assumed that a weak base has a weak intramolecular bond so that it will be ionized/dissociated entirely in solution.

The correct concept of ionization/dissociation of weak base, that is, a weak base ionize/dissociate partially in a solution with a water solvent so that the ionization/dissociation constant of the weak base is small (less than $1.0 \times 10-1$ ) [24]. In the solution with a water solvent, a weak base forms an equilibrium between the base molecules and their ions [22].

\subsection{The Relationship between Acid Strength and pH}

The results showed a significant misconception on the target concept of the relationship of acid strength with $\mathrm{pH}$ consisting of two patterns of misconception. The first pattern of misconception formed because students' understanding of the meaning of the word "pH" was incorrect. Students associated the term $\mathrm{pH}$ as the degree of acidity with the term acid strength that used in classroom learning activities and student chemistry handbooks, so students thought that the higher the $\mathrm{pH}$ value, the stronger the acidic of a solution. This misconception was consistent with the results of research by Demircioglu, et al. (2005) [19] and Metin (2011) [21], who suggested that students experience misconceptions about the concept of acid-base strength and thought that $\mathrm{pH}$ was a measure of acid strength. If the $\mathrm{pH}$ value increases, the acid strength increases. The results of this study reinforced the previous findings which stated that the associative thinking of students was one of the factors forming student misconceptions [4].

Based on interviews and analysis of student handbook chemistry documentation, it was known that the formation of the second pattern misconception in the target concept was based on student reasoning sourced from student handbooks which stated that $\mathrm{pH}$ was a measure of acid strength. The correct concept of the relationship between acid strength and $\mathrm{pH}$ is that $\mathrm{pH}$ is not a measure of acid strength, but $\mathrm{pH}$ only shows the concentration of hydrogen ions [24]. This is in line with what was stated by Effendy (2011, in Amry, et al., 2017, p. 389) that pH indicates the large concentration of $\mathrm{H}^{+}$ions in solution and is not a measure of the strength of an acid [25]. The measure of acid strength is related to the ability of an ionized/dissociated acid in water, which can be expressed by the values of $\mathrm{K}_{\mathrm{a}}$ (acid ionization constant) and $\alpha$ (degree of ionization) [26].

\section{Conclusion}

Based on this research, showed that student of grade XI high school students in Sumedang Regency identified as having a misconception on the concept of acid-base strength consisting of seven target concepts tested, ionization/dissociation of strong acids, reaction of strong acids with metals, ionization/dissociation of weak acids, ionization/dissociation of strong bases, 
electrolyte properties of strong base, ionization/dissociation of weak base, and the relationship between acid strength and $\mathrm{pH}$. The biggest misconception was in the target concept of relationship between acid strength and $\mathrm{pH}$ with a percentage of $51.52 \%$, which consisted of two patterns of misconception, namely (1) the higher the $\mathrm{pH}$ value, the stronger the acidic of a solution because $\mathrm{pH}$ indicates the strength of acid (38.89\%) and (2) the lower the $\mathrm{pH}$ value, the stronger the acidic of a solution because $\mathrm{pH}$ indicates the strength of acid (12.12\%).

Factors that cause grade XI high school students in the Sumedang Regency city area experienced misconceptions on the concept of acid-base strength that was explored through questionnaires, interviews, and documentation of student chemistry handbooks consisting of external factors and internal factors. External factors that influence were (1) the teacher, which includes teaching methods and learning media (tools and practicum materials) used, and (2) the textbook used as a learning resource, which includes clarity of concept exposure and completeness of contents, while internal factors originating from students are students' preconceptions, associative thinking, incomplete/ wrong reasoning, and student abilities.

\section{References}

[1] Dahar, R.W.: Teori-teori belajar dan pembelajaran. Jakarta: Erlangga. (2006)

[2] Treagust, D. F.: Diagnostic assessment in science as a means to improving teaching, learning, and retention. (UniServe Science Assessment Symposium Proceedings). Science and Mathematics Education Centre, Curtin University of Technology, Australia. (2006)

[3] Amry, U. W., Rahayu, S., \& Yahmin. Pengembangan instrumen tes diagnostik two-tier pada materi asam basa. Pros. Semnas Pend. IPA Pascasarjana UM, 1. (2016)

[4] Suparno, P.: Miskonsepsi dan perubahan konsep dalam pendidikan fisika. Jakarta: Grasindo. (2013)

[5] Widiyatmoko, A., dan Shimizu, K.: Literature review of factors contributing to students' misconceptions in light and optical instruments. International Journal of Environmental \& Science Education, 13(10), pp. 853-863. (2018)

[6] Menteri Pendidikan dan Kebudayaan Republik Indonesia.: Peraturan menteri pendidikan dan kebudayaan Republik Indonesia nomor 24 tahun 2016 tentang kompetensi inti dan kompetensi dasar pada kurikulum 2013 pada pendidikan dasar dan pendidikan menengah. Jakarta: Kemendikbud. (2016) [7] Kala, N., Yaman, F., \& Ayas, A.: The effectiveness of predict-observe-explain technique in probing students' understanding about acid-base chemistry: A case for the concepts of $\mathrm{pH}, \mathrm{pOH}$, and strength. International Journal of Science and Mathematics Education, 11, pp. 555-574. (2012)

[8] Sudijono.:Pengantar evaluasi pendidikan. Jakarta: PT Raja Grafindo Persada.

[9] Treagust, D. F. (1988). Development and use of diagnostic tests to evaluate students' misconception in science. Innovations and Developments, 10(2), pp. 159-169. (2007)

[10] Abadzivor, H. E.:Assessment of pictorial materials in Ghanaian pre-school education: A case study in Kumasi Metropolis. (Tesis). Department of General Art Studies, Kwame Nkrumah University of Science and Technology, Kumasi (2006)

[11] Kose, S.: Diagnosing student misconceptions: using drawing as a research method.

Journal World Applied Science, 3(2), pp. 283-293. (2006)

[12] Daryanto.: Evaluasi pendidikan. Jakarta: PT Rineka Cipta. (2014)

[13] Susiani, D.: Profil fisik atlet taekwondo Sleman pada Porprov DIY. (Skripsi). FIK, Universitas Negeri Yogyakarta, Yogyakarta. (2009)

[14] Darmadi, H.: Metode penelitian pendidikan. Bandung: Alfabeta. (2011)

[15] Satori, D. \& Komariah, A.: Metodologi penelitian kualitatif. Bandung: Alfabeta. (2014)

[16] Tan, K. C. D., Taber, K. S., Goh, N. K., \& Chia, L. S.: The ionization energy diagnostic instrument: a two-tier multiple choice instrument to determine high school students' understanding of ionization energy. Chemistry Education Research and Practice, 6(4), pp. 180-197. (2005) 
[17] Dewi, E. P.Pengembangan tes diagnostic two-tier berbasis pictorial untuk mengidentifikasi miskonsepsi siswa pada materi asam basa. (Skripsi). Departemen Pendidikan Kimia FPMIPA, Universitas Pendidikan Indonesia, Bandung. (2015)

[18] Suryaningtyas, H.: Profil miskonsepsi siswa di Kota Cimahi pada materi asam basa menggunakan tes diagnostik two-tier multiple choice berbasis piktorial. (Skripsi). Departemen Pendidikan Kimia FPMIPA, Universitas Pendidikan Indonesia, Bandung. (2016)

[19] Demircioglu, G., Ayas, A., \& Demircioglu, H.: Conceptual change achieved through a new teaching program on acids and bases. Chemistry Education Research and Practice, 6(1), pp. 36-51. (2005)

[20] Artdej, R., Ratanaroutai, T., Coll, R. K., \& Thongpanchang, T.: Thai grade 11 student's alternative conceptions for acid-base chemistry. Research in Science \& Technological Education, 28 (2), pp. 167183. (2010)

[21] Metin, M.: Effects of teaching material based on 5E model removed preservice teachers misconceptions about acids-bases. Bulgarian Journal of Science and Education Policy (BJSEP), 2(5), pp. 275-302. (2011)

[22] Silberberg, M. S. Principle of general chemistry (2nd ed.). New York: McGraw-Hill. (2010)

[23] Whitten, K.W., Davis, R. E., Peck, M. L., \& Stanley, G. G.: General chemistry (10th ed.). Canada: Mary Finch. (2014)

[24] Krieger, P. J.: Understanding chemical principles: A learning companion. United States of America: Susan Katz.

[25] Amry, U. W., Rahayu, S., \& Yahmin. (2017). Analisis miskonsepsi asam basa pada pembelajaran konvensional \& dual situated learning model (DSLM). Jurnal Pendidikan: Teori, Penelitian, dan Pengembangan, 3(2), pp. 385-391. (1999)

[26] HAM, M.: Ilmu kimia 2 untuk SMU/MA kelas 2 (ed. kedua). Bandung: Acarya Media Utama.(2002) 